Proceedings

\title{
The impact of urban sprawl in suburban area of Rajshahi: A study in Kashiadanga area
}

1 Undergraduate student; e-mail: 1607012@student.ruet.ac.bd

2 Assistant Professor; e-mail: ferdous.huq08buet@gmail.com

3 Lecturer; e-mail: muhaiminul.urp13@gmail.com

* Correspondence: e-mail: 1607012@student.ruet.ac.bd;

Citation: Murad, M.; Hossain, M.; Jahan, T; Huq, F.; Islam, M., 2022, The impact of urban sprawl in suburban area of Rajshahi: A study in Kashiadanga area. SUPTM 2022 conference proceedings sciforum-049743. https://doi.org/10.31428/10317/10484

Publisher's Note: UPCT and Sciforum stays neutral with regard to jurisdictional claims in published maps and institutional affiliations.

Copyright: (c) 2022 by the authors. Submitted for possible open access publication under the terms and conditions of the Creative Commons Attribution (CC BY) license (https://creativecommons.org/license s/by/4.0/).

\begin{abstract}
Urban sprawl is one of the most vital features of urbanization. This study investigates the change of landuse pattern and its impact on the area's physical environment, which is on the edge of Rajshahi City Corporation, Kashiadanga. Spatial analysis was used to detect the landuse change and different PRA tools investigated the utility problems resulting from urban sprawl. A large amount of deterioration of natural resources are the result of scattering development. Dwellers of the area are deprived of basic utility facilities and the quality of life also worsens day by day. The pressure of increasing the population is tough to manage without any proper development plan.
\end{abstract}

Keywords: Urban sprawl, spatial analysis, utility facility, PRA.

\section{Introduction}

Bangladesh has an estimated population of 164.69 million by the year 2020. In 2011 urban population growth rate in Bangladesh was 3\%. (BBS, 2015). In a developing country, the expansion of a city is not properly monitoring by responsible authorities and it causes urban sprawl on out edges of a city. This peri-urban area has both rural and urban characteristics. In comparison to compact growth, urban sprawl is characterized by lowdensity development, rapid and fragmented development, and poor accessibility (Wang et al., 2019). In developing countries, lower-income people live in sprawling areas because of the low house rent rate compared to the core city. A high rate of unauthorized development is taking place along with the road connectivity. A large number of agricultural lands and greeneries are hampered by urban sprawl (Dubey \& Kumar, 2013). The total population of Rajshahi city is about 0.85 million with a density of 4,318/Sq Km (Worldwide, 2020). In 2010, Rajshahi's urban extent increased by 6009 hectares at an average annual rate of 8.5 percent from 2000 (Atlas of Urban Expansion - Rajshahi, 2020). Between 2000 and 2010 about 1832 hectares of the built area had been added to Rajshahi city (Atlas of Urban Expansion - Rajshahi, 2020). In the year 1991-2001, cropland was reduced annually by $1.28 \%$, while during $2001-2008$ the percentage was about $1.62 \%$ in the sub-urban area of Rajshahi (Rahman, 2010). In 1991, 2001 and 2008 land under housing was about $9.28 \%, 11.87 \%$, and $15.69 \%$ of the total land in Rajshahi's sub-urban area (Rahman, 2010). The urban sprawl creates an inadequate supply of urban facilities like water supply, electricity, sanitation services, waste collection etc. in the sprawling area. Kasiadanga is one of the most important and busy suburban areas of Rajshahi. The increasing population creates a huge change in the landuse of the area. Mainly, the farming land started decreasing as to cope with the increasing housing or infrastructures. The housing settlements are increasing at high speed, but utility services are not increasing at similar pace. Although the area is under the RCC control and has some urban amenities, they are very inadequate for residents (Rahman, 2010). 


\section{Area of study}

Kasiadanga is a sub urban area of Rajshahi city in Bangladesh. It is situated at the north-west portion of the Rajshahi city corporation area. There is a main activity center in the kasiadanga which is junction of the roadway where the Chapai Nawabgonj- Rajshahi highway, city and bypass road meets together as well as there is another connection road with Rajshahi and Kakonhat.

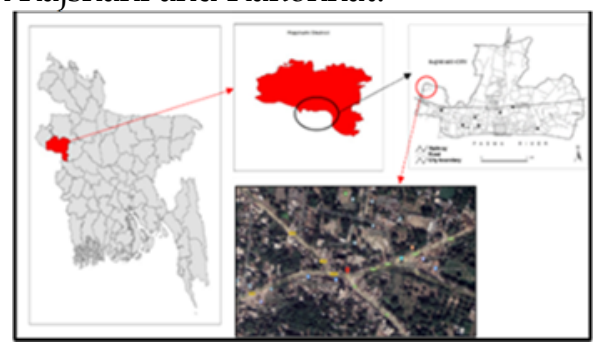

Figure 1. Map of Kashiadanga (Source: Google earth, 2020))

\section{Methodology}

The primary data were mainly collected with the help of the PRA tools (Focus group discussion, cause effect diagram, pair wise ranking, Venn diagram, dream map and so on) and the secondary data were collected and analysed satellite images with remote sensing. After all these processes, this study tried to find the impact of urban sprawl on the utility services and the mismanagement.

\section{Results}

\subsection{Existing situation of Kashiadanga}

Three local communities were helping to develop this social map of Kashiadanga. Residential buildings are situated behind of commercial buildings. According to participants, lack of access road creating a problem for entering to the residential zone. Most of the buildings are tin shade houses and very few two or three-storied buildings.

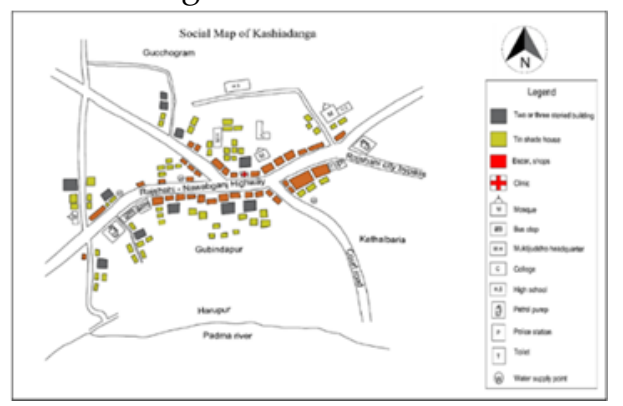

Figure 2. Existing map of Kashiadanga (Source: Field survey, 2020)

\subsection{Changes in the different time period}

Table 1. Timeline incident analysis

\begin{tabular}{cr}
\hline Time period & Incidents \\
\hline Before independence (1965-1970) & Kashiadanga to Court Road construction \\
\hline Just before independence (1970-1971) & Tertiary road of ward 1 construction \\
\hline 1990 & Klectricity introduced in Kashiadanga \\
\hline 1995 & Kakhiadanga became a part of Rajshahi city corporation \\
\hline 1997 & Kashiadanga mor bazar started with a less amount of shops \\
\hline $2005-2006$ & Kashiadanga bazar started development at a high speed \\
\hline $2010-2013$ & Water supply from city corporation introduced in some points
\end{tabular}




\begin{tabular}{cc}
\hline $2015-2016$ & Land price started increasing at a high speed \\
\hline $2015-2016$ & Farmers started selling their agricultural lands \\
\hline $2017-2018$ & Waste collection from city corporation started but not in a regular basis \\
\hline 2018 & 7 storied building constructed at the central point of kashiyadanga bazar \\
\hline At present & Different 2 to 3 storied buildings are developing for housing \\
\hline
\end{tabular}

Different utility services are then introduced in different periods like electricity in 1990, water supply in 2013-15 and so on. In 2015-16, the land price started increasing at high speed and in the meantime farmers of this area started selling their agricultural land

\subsection{Land use changes of Kashiadanga}

The figures representing the land use of the area in 2010 and 2019 respectively. From these figures the degradation of nature and increasing developed area in almost 10 years can be observed. In the year 2010, the build-up area was almost of $0.0369 \mathrm{~km}^{2}$ and in the 2019 it became $0.2266 \mathrm{~km}^{2}$ which is a huge change in landuse.

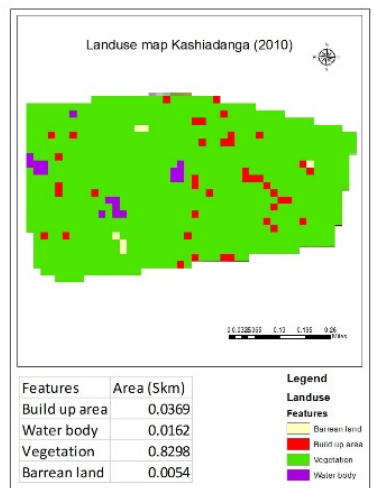

(a)

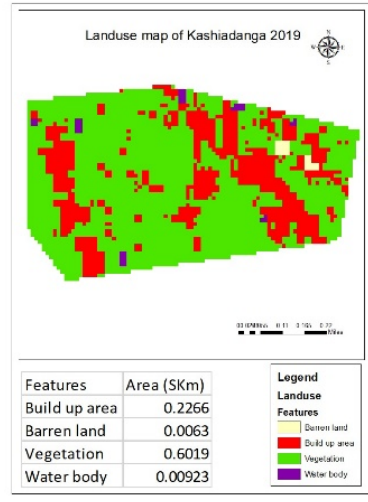

(b)

Figure 3. (a) Landuse map of Kashiadanga in the year 2010 (b) Landuse map of Kashiadanga in the year 2019

\subsection{Institution Impact on Urban sprawl}

Mostly the Kashiadanga bazar has the greatest influence as most of the residents around Kashiadanga are directly or indirectly dependent on this local market place. The ward counselor office is the second most influential institute found in the area. According to the respondents of the PRA survey, this institution does not give proper attention to their needs. However, they maintain connectivity with the institute to inform the counselor about their problems.

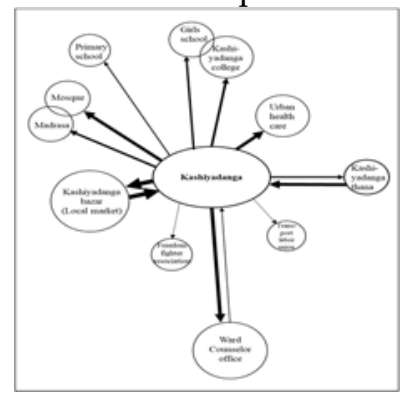

Figure 4. Venn diagram for institutional impact (Source: Field survey, 2020)

\subsection{General impact of Urban sprawl on Kashiadanga area}

Table 2. Cause-effect analysis of general impact of urban sprawl

\begin{tabular}{|c|c|c|c|c|}
\hline Effect & $\begin{array}{l}\text { Uncontrolled develop- } \\
\text { ment }\end{array}$ & $\begin{array}{l}\text { Housing density } \\
\text { increasing }\end{array}$ & Degradation of agricultural land & Lack of utility facilities \\
\hline & 仓 & 仓 & 仓 & 仓 \\
\hline
\end{tabular}




\begin{tabular}{|c|c|c|c|c|}
\hline Problem & & & Urban Sprawl & \\
\hline & 仓 & 仓 & 仓 & 仓 \\
\hline Cause & $\begin{array}{l}\text { Lack of application of } \\
\text { rules and regulations }\end{array}$ & $\begin{array}{l}\text { Population den- } \\
\text { sity }\end{array}$ & $\begin{array}{c}\text { Less land price than other areas of } \\
\text { Rajshahi city corporation }\end{array}$ & Lack of proper management \\
\hline
\end{tabular}

The respondents of the PRA survey have noted uncontrolled development, increasing housing density, agricultural land degradation and lack of utility facilities as the major effects of urban sprawl. According to the resident urban sprawl is the result of lack of application of rules and regulations, increasing population.

\subsection{Impact of urban sprawl on utility services}

Table 3. Cause-effect analysis of urban sprawl on utility services

\begin{tabular}{|c|c|c|c|c|c|c|c|c|}
\hline Effect & $\begin{array}{l}\text { Access road } \\
\text { problem }\end{array}$ & $\begin{array}{l}\text { Water supply } \\
\text { problem }\end{array}$ & $\begin{array}{l}\text { Waste collection } \\
\text { problem }\end{array}$ & $\begin{array}{l}\text { Generation } \\
\text { of garbage }\end{array}$ & $\begin{array}{l}\text { Water } \\
\text { logging }\end{array}$ & $\begin{array}{l}\text { Drainage } \\
\text { problem }\end{array}$ & $\begin{array}{l}\text { Streetlight } \\
\text { problem }\end{array}$ & $\begin{array}{l}\text { Electricity } \\
\text { problem }\end{array}$ \\
\hline & 仓 & & 仓 & & & 仓 & & \\
\hline Problem & \multicolumn{8}{|c|}{ Lack of utility services } \\
\hline & 仓 & & & 仓 & 仓 & \multicolumn{3}{|c|}{ ث } \\
\hline Cause & $\begin{array}{l}\text { Lack of } \\
\text { providing }\end{array}$ & $\begin{array}{l}\text { Inadequate } \\
\text { water }\end{array}$ & Lack of dustbin & $\begin{array}{l}\text { Lack of } \\
\text { manpower }\end{array}$ & $\begin{array}{l}\text { Absence of } \\
\text { drainage }\end{array}$ & \multirow{2}{*}{\multicolumn{3}{|c|}{ Lack of proper management }} \\
\hline & access road & connection & & & system & & & \\
\hline
\end{tabular}

Because of unplanned development, most of the site's houses do not have access roads and it also generates problems to provide utility services. The absence of proper drainage systems and stormwater flow channel makes life more difficult than ever in monsoon time. Every day huge amounts of garbage are generated in the area but lack of human resources and proper management of the trash remains in the road for a long time.

\section{Conclusion}

Urban sprawl mainly occurred on the outskirts of a city. The study area is the outside edge of Rajshahi City Corporation and has undergone substantial urban land use changes in the last decades. Urban sprawl is the reason for massive land use changes and it also affects the quality of life of dwellers of the area. The discreet settlement is the reason of urban sprawl and this settlement destroys a massive amount of agricultural land and vegetation area. Dwellers of the study area are deprived of essential utility services though the site is under RCC jurisdiction. Dwellers of the area are deprived of basic utility facilities and the quality of life also worsens day by day. The pressure of increasing the population is tough to manage without any proper development plan. As a result, a rational urban planning policy is required to mitigate the negative consequences of urbanization. Funding: This research received no external funding.

\section{References}

1. Atlas of Urban Expansion. (2016). Rajshahi. Retrieved from http://atlasofurbanexpansion.org/cities/view/Rajshahi

2. $\quad$ BBS. (2015). Bangladesh Statistical Year Book. Dhaka: Bangladesh Bureau of Statistics.

3. Dubey, P., \& Kumar, M. D. (2013). Urban Sprawl and its Impact on Urban Environment. Journal of Mechanical and Civil Engineering, 9(5), 26-31. URL: https://www.iosrjournals.org/iosr-jmce/papers/vol9-issue5/E0952631.pdf?id=7622

4. Kashem, M. S., Chowdhury, T. A., Majumder, J., \& Rahman, M. A. (2009). Quantifying Urban form: A Case Study of Rajshahi City. Journal of Bangladesh Institute of Planners, 2, 39-48.URL: https://www.banglajol.info/index.php/JBIP/article/view/9555

5. Rahman, M. (2010). Factors of economic transformation in sub-urban areas of Rajshahi City, Bangladesh. Journal of Life and Earth Science, 5, 47-55. doi: 10.3329/jles.v5i0.7350

6. Wang, J., Qu, S., Peng, K., \& Feng, Y. (2019). Quantifying Urban Sprawl and Its Driving Forces in China. The journal of Discrete Dynamics in Nature and Society, 14. doi: https://doi.org/10.1155/2019/2606950

7. Worldwide, S. (2021). Rajshahi. Retrieved 8 December 2021, from https://sfd.susana.org/about/worldwide-projects/city/151rajshahi 